\title{
FRA ADFARDSSTYRENDE KONTROL TIL INDIVIDUEL DIGITAL MEDIERING
}

\author{
Kritisk teknologiteoretisk analyse af dagpengesystemets digitale \\ ressourcer
}

\section{LINE STEENHOLD OG TOM BØRSEN}

Udviklingen af teknologier i søgen efter effektivisering er ikke noget nyt (Mokyr et al. 2015). I juni 2016 blev lov nr. 624 om aktiv beskæftigelsesindsats vedtaget, hvilket betyder øget digitalisering og ny IT-understøttelse i dagpengesystemet. A-kassernes brancheorganisation kritiserede lovændringen for at give et endnu mere komplekst dagpengesystem (Ritzau 2016). Karsten Mølgaard Jensen (2018), administrerende direktør i a-kassen ASE, er enig og støtter op om et forslag fra Det Radikale Venstre om at samle beskæftigelsesindsatsen ét sted: i a-kasserne. CEPOS beskylder dagpengesystemet for at være dyrt og ineffektivt. Den liberale tænketank har regnet sig frem til, at det koster 4-500.000 kroner at få en ledig i arbejde (Ishøy 2019a). En undersøgelse fra YouGov i B.T. konkluderer, at kun 1 ud af 10 ledige kommer i job på grund af en indsats fra jobcentret (Ishøy 2019b).

Organiseringen af det danske arbejdsmarked kaldes også den danske model. Den består af trepartssamarbejde, kollektive overenskomster og høj organisationsgrad (Beskæftigelsesministeriet u.d.). Der er i Danmark 23 statsgodkendte arbejdsløshedskasser (a-kasser), der tilbyder arbejdsløshedsforsikringer (STAR 2020). Systemet var oprindeligt baseret på solidaritet mellem arbejdstagere, men er i dag blevet institutionaliseret gennem omfattende lovgivning. Den ændres jævnligt som i 2016, hvor digitaliseringen forøgedes. Denne institutionalisering har medført en følelse af utryghed blandt ledige (Dagpengekommissionen 2015). Generelt er ledige bekymrede for deres levestandard og sociale status. Dette gælder også i et velfærdssamfund som det danske, hvor man kan modtage offentlig understøttelse, der sikrer overlevelse, men betyder en væsentlig nedgang i levestandard (Nordt et al. 2015).

Men kritikken går uden om de digitale platforme, som understøtter dagpengesystemet, og som lovændringerne har styrket. Der har været ganske få studier af brugere af velfærdstjenester og konsekvenserne af ny teknologi for brugere. En norsk undersøgelse konkluderer, at digitale møder ikke har erstattet fysiske 
møder, og at oplevelsen af den digitale teknologi afhænger af brugerens digitale færdigheder (Hansen et al. 2018). Forsikrede ledige skal i dag gennemføre deres pligter på to digitale platforme: Jobnet.dk, jobcentres offentlige platform, samt egen a-kasses website. De digitale platforme har stor indflydelse på lediges hverdag, fordi de er et såkaldt obligatorisk passagepunkt (Callon 1984:7) for alle dagpengemodtagere. På den ene side er der en intention om at støtte de ledige $\mathrm{i}$ deres jobsøgning. På den anden side findes en opfattelse af, at det er nødvendigt at kontrollere, hvilket forfatter og politisk skribent Larsen (2013) betegner som forståelsen af ledighed som selvforskyldt og begrundet i dovenskab. I dette perspektiv kan ledighed forhindres af øget kontrol og økonomiske sanktioner (Pultz 2018a). Det danske ledighedssystem adfærdsstyrer de ledige ved hjælp af digitale styringsværktøjer, idet ledige risikerer at få frataget retten til dagpenge, hvis de ikke benytter de digitale platforme korrekt.

Denne artikel ser nærmere på, om ledige opfatter de digitale platforme som nyttige i jobsøgningen, og - hvis ikke - hvordan de kan transformeres, så de i højere grad opfattes som sådan af de ledige brugere. Dette vil øge forståelsen af dagpengesystemets digitale ressourcer, som er underbelyst i forskningslitteraturen, og gøre det lettere at målrette dem lediges interesser og virkelighed.

Artiklens første del præsenterer de tekniske elementer, som ledige møder i dagpengesystemet, og viser, hvordan ledige opfatter dem. Om de mener, at elementerne støtter dem i deres jobsøgning eller modarbejder dem (ifald de opfattes som meningsløse, spild af tid, stressende eller ubehagelige at benytte). I artiklens anden del gengives lediges forslag til, hvordan dagpengesystemets digitale platforme kan forbedres, så de i højere grad tilgodeser lediges interesse.

\section{Teori og empiri}

Som præmis for denne undersøgelse ligger Andrew Feenbergs kritiske teknologiteoretiske (KTT) tilgang, som er præsenteret i de to hovedværker Transforming Technologies. A Critical Theory Revisited fra $2002 \mathrm{og}$ Technosystem. The Social Life or Reason fra 2017. Denne tilgang antager, at teknologi er indlejret i og filtret sammen med normative fordringer $-\mathrm{fx}$ sociale interesser, normer, værdier og lovgivning $-\mathrm{i}$ en sådan grad, at disse sociale elementer former det tekniske design. Teknologier besidder intentionalitet, deres tekniske design retter sig mod givne formål, idet normative fordringer er indskrevet og afspejles i det tekniske design (Børsen 2020: 226). Det kritiske teknologiteoretiske perspektiv ser ikke teknologi og kultur som to modpoler, men som to elementer, der former hinanden (Feenberg 2002).

Om en teknologi fremmer eller negligerer en brugergruppes interesser, afhænger af, hvilke formål der er indlejret i det tekniske design, hvad teknologien 
retter sig mod, og hvordan brugergruppens repræsentanter vurderer teknologiens formål og virkning (Immervoll et al. 2020). Således opfattes teknologi og teknisk design ikke som blotte redskaber, der kan spændes for vilkårlige interesser, fordi et specifikt teknisk design fremmer specifikke formål og interesser.

Den kritiske teknologiteoretiske tilgang har blandt andet formet vores blik på dagpengesystemets digitale platforme: Vi kigger i undersøgelsen på den intentionalitet - de formål og virkninger - som platformenes tekniske design har. De digitale platforme får ledige til at gøre bestemte ting og undlade at gøre andre.

Ofte vil det være sådan, at der ikke er overensstemmelse mellem et teknisk designs intentionalitet (formål og virkning) og en påvirket gruppes interesser. Feenberg beskæftiger sig i sine analyser blandt andet med, hvordan teknologi ekskluderer medarbejderes, patienters, miljøaktivisters og hjemløses interesser. Der kan være mange årsager til, at en gruppes interesser ikke afspejles i et teknisk design (kulturelle, økonomiske, politiske, administrative).

Fremfor at dvæle ved disse årsager søger KTT-inspirerede undersøgelser at vise, at undertrykkende teknologi kan omformes, så den afspejler berørte, ofte sårbare gruppers interesser. Analyser inspireret af KTT er interesserede i at sikre, at disse gruppers interesser afspejles i de teknologiske løsninger, deres repræsentanter møder og påvirkes af.

Centralt i kritisk teknologiteori står forestillingen om, at det ikke behøver være sådan, men at ekskluderende teknologi kan omformes, så den også tjener brugergruppers ekskluderede interesser (Feenberg 2002). Målet med kritiske teknologiteoretiske undersøgelser er at vise, at dette er muligt. Man kan ikke bare bruge teknologien på en anden måde; teorien dikterer et nyt teknisk design.

Den kritiske teknologiteoretiske tilgang har formet vores fokus på den teknologi, som ledige møder, når de indrulleres i dagpengesystemet, samt på, hvordan ledige opfatter systemets digitale platforme. Vi siger, at de digitale værktøjer tjener lediges interesser, hvis ledige selv mener og kan forklare, hvordan en digital funktion understøtter deres jobsøgning. Hvis de ikke får støtte af et digitalt værktøj, men tvinges til at benytte det, bliver lediges interesser ikke tilgodeset.

Hvis dagpengesystemets digitale platforme får ledige til at gøre ting, de finder meningsløse, spild af tid, stressende eller ubehagelige, antager vi, at det tekniske design kan forandres, så ledige finder dem meningsfulde og nyttige i deres jobsøgning.

Feenberg (2002:184) kalder det at rekontekstualisere en teknologi. Udgangspunktet for teknologiers rekontekstualisering er inddragelse af de undertrykte gruppers ellers ekskluderede perspektiv. Dette kalder Andrew Feenberg at demokratisere teknologien (op.cit.153). To forskellige konfigurationer af en given teknologi kan begge opnå et højt effektivitetsniveau; en ved at udvikle brugernes færdigheder, mens den anden eliminerer dem. Under forskellige sociale forhold 
og værdier kan hver enkelt konfiguration være vellykket (ibid.). Vil man ændre et samfund, en institution eller en praksis, er teknologisk innovation og teknologisk forandring et godt sted at begynde. Dette mener vi også gælder dagpengesystemets digitale platforme, som både kan støtte ledige i jobsøgningen og „tvinge“ ledige til at gøre noget, de finder meningsløst, spild af tid, stressende eller ubehageligt. Vil man forbedre lediges situation, er den teknologi, ledige møder, et godt sted at rette fokus.

Første trin i Feenbergs teknoantropologiske tilgang er at beskrive den teknologi, man ønsker at rekontekstualisere - det vil sige at beskrive teknologiens tekniske elementer og implicerede sociale interesser, der tilsammen konstituerer den teknologi, man søger at forandre. Dette kalder Feenberg at dekontekstualisere teknologien. Herefter følger den ovenfor nævnte rekontekstualisering, hvor ekskluderede interesser tilføjes til teknologien som omarrangerede eller nytilføjede tekniske elementer med forandret intentionalitet. Feenberg er selv opmærksom på, at en eksisterende teknologi sjældent fuldstændig inkluderer eller ekskluderer en brugergruppes interesser. Enhver teknologi afspejler i forskellig grad begge dele. Pointen i en KTT-tilgang er gennem demokratisk deltagelse at ændre på forholdet mellem indlejrede interesser og intentionaliteter i en given teknologi. Dagpengesystemet skal både disciplinere og støtte ledige. Dagpengesystemets digitale ressourcer kan derfor på samme tid både disciplinere og støtte ledige $\mathrm{i}$ deres jobsøgning (Ekspertgruppen 2014). Vi har valgt en kritisk etnografisk metode til empiriindsamling (Masemann 1982). Empirien består af:

1. Deltagende observation på syv møder med a-kasser, hvor nye ledige bliver introduceret til dagpengesystemets digitale styringsværktøjer samt dets pligter og regler. Alle nye ledige skal møde op til et intromøde. Observationerne er gennemført for at få indsigt i lediges livsverden og få forståelse af den information, om de digitale styringsværktøjer, ledige modtager (Krogstrup \& Kristiansen 1999). Efter møderne blev noter og fotos omskrevet til „tætte beskrivelser“ (Geertz 1973).

2. Interviews med 30 ledige. Interviewpersonerne er blandt andet rekrutteret direkte $\mathrm{i}$ forbindelse med observation på intromøderne og gennem uddeling af flyers på jobcentre og a-kasser samt sociale medier.

Når ledige kontaktede os for at tilmelde sig et interview, startede de i narrativer. Derfor er interviewene organiseret som semistrukturerede livsverdensinterview med plads til at forfølge narrativerne. Denne fleksibilitet gav mulighed for at komme helt tæt på lediges praksis (Brinkmann \& Tanggaard 2015).

3. Interviews med 19 jobkonsulenter og ledere i a-kasser og jobcentre.

Gældende for alle interviews er, at der blev givet tid til, at informanterne kunne tale ud, og informanterne havde meget at fortælle. Det er tilsyneladende 
et følsomt emne. Derfor har interviewene en tidslig udstrækning på en-tre timer for at give plads til fleksibilitet og sensitivitet (Pultz 2018b). Både ledige akassemedlemmer samt jobkonsulenter og andre medarbejdere på dagpengeområdet har overvejelser om sanktioner i forhold til at deltage i interviews, og derfor er alle anonymiseret. ${ }^{1}$

Interviewene er overordnet opdelt $i$ tre hovedtemaer: informanternes kritik af dagpengesystemets digitale ressourcer, hvilke positive aspekter informanterne forbinder med de digitale platforme og informanternes forslag til forbedring af de digitale ressourcer.

\section{Dekontekstualisering af dagpengesystemets digitale ressourcer}

Ledige, der modtager dagpenge, har pligt til at udføre bestemte handlinger for at blive anset som ledige. Mange af de pligtbaserede handlinger skal udføres på digitale værktøjer:

De digitale løsninger i beskæftigelsesindsatsen har overordnet set tre forskellige formål: a) bedre service, b) effektivisering af administrative processer og c) styring af brugeres adfærd. Ofte vil digitale løsninger opfylde flere af formålene sideløbende. Traditionelt er IT-løsninger tæt forbundet med ønsket om effektivisering af administrative processer. Digitale værktøjer bidrager i stigende grad også til at påvirke adfærden blandt borgere, virksomheder og systemet (Ekspertgruppen 2014:69).

Flertallet af de digitale pligter udføres på Jobnet.dk, som er et website udviklet af Styrelsen for Arbejdsmarked og Rekruttering (STAR) i samarbejde med Kommunernes Landsforening. Jobnet.dk er målrettet understøttelse af lediges jobsøgning via Jobbank, CV-bank og informationssider. Herunder information om/fra det lokale jobcenter (Jobnet 2015). Jobnet.dk har 2 millioner besøgende om måneden (Jobnet u.d.c). Andre pligter udføres på a-kassens website. Nogle pligter kan både udføres på Jobnet.dk og på a-kassens website. Udføres de digitale pligter ikke, kan der komme en økonomisk sanktion eller sågar udmelding af systemet. Det er ikke alle digitale ressourcer, som ekspliciteres her i artiklen. Figur 1 giver en oversigt over lediges digitale pligter. 


\section{DIGITALE PLIGTER}

Udfylde ledighedserklæring hos egen a-kasse

Melde sig ledig på jobnet.dk

Oprette CV på jobnet.dk under modulet Min Jobsøgning

Udfylde Min Plan på jobnet.dk under modulet Min Side

Udfylde dagpengekort på a-kassens selv-service side

Booke moder på jobnet.dk eller a-kassens hjemmeside (alt efter hvem man skal til møde med)

Registrere/uploade 1-2 ansogninger om ugen under modulet Min Jobsogning eller på a-kassens joblog

Dagligt tjekke og reagerere på henvendelser fra jobcenter, a-kasse eller anden aktør

Tjekke jobforslag hver 7. dag på jobnet.dk under modulet Min Side ved at trykke 'Tjek jobforslag'

Godkende Min Plan på jobnet.dk under modulet Min Side efter man har været til mode

Overholde Min Plan f.eks. den aftalte sogeadfærd

Sygemelde sig på jobnet.dk under modulet Min Side

Melde sig rask på jobnet.dk under modulet Min Side

Melde hvis man får midlertidig adresse på jobnet.dk under modulet Min Side

Melde ferie senest 14 dage for på jobnet.dk under modulet Min Side

Figur 1. Digitale værktøjer, der styrer lediges pligter.

\section{Digital uigennemskuelighed}

For at blive anset som ledig skal man melde sig ledig digitalt på Jobnet og a-kassens website. Man skal udfylde en ,ansøgning om dagpenge“ hos egen a-kasse, og man skal bruge blanketter til ansøgning om ferie; hvis man er selvstændig, får eller ønsker supplerende dagpenge, vil være frivillig etc. Under hver kategori er blanketterne opdelt i undergrupper, alt efter hvilken situation ansøger står $\mathrm{i}$. Uanset længden af ledighedsperiode beskriver ledige, at der på a-kassens website er mange blanketter - listen over blanketter fylder syv A4-sider udskrevet - og at det er svært at finde den rigtige blanket. Det betyder, at mange kommer til at udfylde den forkerte blanket, som Noah, der forklarer: ,[D]er var frygtelig mange 
blanketter, og nogle af dem var tvetydige, også selv om man kunne trykke på et ikon ved siden af, der hedder 'råd og vejledning'" (Noah, ledig). Det samme udtaler Lily, som er medlem af en anden a-kasse. Da hun skal melde sig ledig, kan hun ikke finde den rette blanket. Hun bruger 20 minutter på at klikke rundt for at finde blanketten, hun tror, hun skal bruge: „Wauw, er det kun mig, der synes, at det her er vildt besværligt. Det er jo helt absurd [hun sukker dybt, og det er, som om hendes klik med musen bliver højere]" (Lily, ledig).

Informationsmængden og sproget spiller også ind. Aya synes, at de lange sætninger er med til at gøre det komplekst at navigere i den digitale informationsmængde og finde de rette blanketter:

Jeg vil gerne benytte mig af nyuddannedes rettigheder inden for blablablabla. Ja, men jeg vil også gerne benytte mig af de andre muligheder, så hvad er det lige, jeg skal vælge? Det kunne bare have være meget mere simpelt, altså. De kunne have skrevet det kort og præcist (Aya, ledig).

Der en sammenhæng mellem informationsmængden, mange blanketter at vælge imellem, forståelsen af det skrevne og forvirring hos ledige om, hvem der forvalter deres digitale pligter: „Jeg synes det med jobcentret og a-kassen har været lidt svært at finde ud af: Hvem gør hvad og hvorfor ..." (Carsten, ledig). Et flertal af ledige har svært ved at kende forskel på arbejdsfordeling og modus operandi mellem a-kasse, fagforening og jobcenter. Dette kan være forklaringen på, at ledige ikke kan sortere i informationsmængden, da det fremstår uklart, $h v o r$ de forskellige digitale pligter skal udføres, når man som ledig ikke ved, hvem som står for hvad: Er det på Jobnet eller på egen a-kasses website? Det medfører forvirring i forhold til, hvad der synkroniseres mellem Jobnet.dk og a-kassens website, og gør det svært at finde ud af, hvilke retningslinjer der skal følges:

Nej, jeg har heller ikke særlig godt styr på det. Jeg synes faktisk, det er rigtig svært at finde information. Eller, der står rigtig meget information på de to sider, du er tilknyttet [Jobnet og a-kassens website]. Det er de to sider, du hele tiden skal opdatere. Og jeg har meget svært ved at finde ud af, hvordan de virker sammen. Kommunikerer de overhovedet? Altså, hvordan er tingene forbundet? Fordi det fremgår ikke rigtigt (Mille, ledig).

En a-kasseleder er inde på noget af det samme og forklarer, hvorfor det er svært for medlemmerne:

Der er rigtig mange aktører, og der er rigtig meget information, der bliver gentaget. Selv om der er et koordinerende samarbejde mellem jobcenter og a-kasse, så er der ikke særligt meget samarbejde, når det handler om information og koordination [mellem jobcenter og a-kasse] (Mette, a-kasse, lederniveau). 
Flere af informanterne oplever det som unødigt svært at navigere i blanketterne, hvilket gør, at de udfylder blanketterne forkert eller fortæller, at de er bange for, at de har udfyldt dem forkert. Det er hverken i de lediges eller dagpengesystemets interesse, da der skal bruges tid på at udrede situationen. Og både ledige og jobkonsulenter forklarer, at de skal arbejde dobbelt tid for at udrede fejl, hvis noget går galt. Andre informanter beskriver det som akut vigtigt at kunne få fat på en person, som de kan spørge til råds om, hvordan man udfylder blanketter korrekt, eller hvis der opstår et andet problem. Akutte problemer beskriver ledige som situationer, der kan resultere i økonomisk sanktion og kan løses af en jobkonsulent med det samme.

Hvis blanketterne eller de digitale systemer er svære at gennemskue eller fejlbehæftede, og der bliver taget yderlige kontakt til jobcenter eller a-kasse for at få svar eller få løst et problem, har nogle af de ledige erfaringer med, at der ikke er enighed om, hvad der er gældende for den enkelte. Ledige oplever modstridende digitale udmeldinger, der omhandler dagpengekortet, ferie, supplerende dagpenge, frivilligt arbejde, selvstændig virksomhed osv. Aksel føler, at han ,er nødt til selv at undersøge, om systemerne stemmer overens. Det kan da ikke passe, at jeg skal forsikre mig om, at det, som jobcentret siger, også er det, som akassen fortæller mig“ (Aksel, ledig). Reglerne er de samme, men informationen er skrevet på forskellig måde på de forskellige websites, hvilket gør ledige usikre på, om de gør det rigtige. Det opleves både af jobkonsulenter hos a-kasser og jobcentre, hvor konsulenter bruger begrebet „kamp“. Wafa forklarer: „Jeg synes godt, det kan føles som lidt af en kamp, når ledige ringer ind og igen har fået forkert information af a-kassen“ (Wafa, a-kassejobkonsulent).

\section{Book møde}

Første fysiske møde med dagpengesystemet er et fællesmøde med andre ledige. Ledige har forinden udfyldt og oprettet et CV på Jobnet.dk, som skal godkendes af a-kassen på mødet. De efterfølgende individuelle møder skal ledige selv booke på Jobnet.dk (Jobnet n.d.b) eller a-kassens website, alt efter hvem man skal til møde med. Alle pligter og frister skal overholdes for at undgå økonomisk sanktion. Man kan selv beslutte, hvornår et møde skal finde sted, og hvilken jobkonsulent man vil mødes med. Dette udfordres af, at en booket jobkonsulent alligevel ikke er i stand til at deltage i mødet. Emma forklarer:

Også sidste gang, jeg planlagde et møde gennem Jobnet.dk, aflyste konsulenten, og jeg måtte planlægge og indkalde igen. Jeg kunne vælge, hvem jeg gerne ville tale med. Jeg kunne vælge mellem tre eller fire konsulenter. Til sidst viste det sig at være en helt femte, jeg skulle mødes med. Hvorfor skal jeg så overhovedet kunne 
vælge? Og helt ærligt, så føler jeg ikke, at systemet er transparent. Heller ikke for de mennesker, der arbejder hos a-kassen eller i ministeriet (Emma, ledig).

Muligheden for at booke møder beskrives også som ligegyldig, uforståelig og ineffektiv, når styringsværktøjet ikke giver medbestemmelse eller ikke virker efter hensigten. „Book møde“ medierer ikke medbestemmelse og medindflydelse. Hvis den ledige faktisk kunne booke møde med den samme jobkonsulent, kunne det give en mere strømlinet og individuel indsats. Det er dog de færreste, der oplever dette i praksis. „Book møde“ medierer heller ikke digital individualitet. Andre ord, som forbindes med denne funktion, er rodebutik, frustrerende og dumt.

\section{Tjek jobforslag og forslag}

Det, som koster ledige flest penge, er, hvis de glemmer at bekræfte, at de er jobsøgende, ved at trykke på knappen „Tjek dine jobforslag“ på Jobnet under „Min side“. Det skal gøres hver syvende dag, og hvis man glemmer det tre gange $\mathrm{i}$ træk, bliver man anset som ikke-ledig og afmeldt, og så skal man genindmeldes. Alle jobkonsulenter, vi har talt med, udtaler, at de kun ønsker at hjælpe ledige med at komme i job.

På et intromøde forklarer jobkonsulenten:

Jeg får rigtig mange spørgsmål om, hvorfor det er netop de her jobforslag, I får. Og jeg ved det desværre ikke. Jobcentrene siger, at Jobnet søger på nøjagtig samme måde, som andre søgemaskiner gør. Hvis det rammer helt ved siden af, så prøv lige at gå ind i jeres Jobnet-CV og tjek, om der nogle af jeres kvalifikationer, der skal ændres. Jer, der jobsøgningsmæssigt er inden for den brede paraply, får altså også tilbudt rugbrødsjob, hvis jeres profil fx omfatter salg (observation af fællesmøde).

Det digitale styringsværktøj „Tjek jobforslag“ er et digitalt kontrolværktøj på Jobnet.dk, hvor den ledige bekræfter at stå til rådighed. Tjek jobforslag-funktionaliteten frustrerer og beskrives som „dum“, „,helt godnat“ og ,,irriterende“: „Men det virker bare absurd, at jeg bare skal tjekke et jobforslag. Det viser jo ikke, at jeg fucking gør noget som helst. Jeg synes, det er irriterende, at det er sådan en syvdagesting“ (Pernille, ledig). Når der trykkes på „Tjek jobforslag“, genereres der jobforslag. Disse opfattes ofte som ikke relevante, når de ikke passer med uddannelse, ønskede arbejdsområde eller erfaringer indskrevet i det digitale CV:

Men jeg har jo skrevet de ting, jeg har lavet. Altså, jeg har jo ajourført med alle mine erfaringer. Jeg har svært ved at se, det peger i retning af pædagogstillinger. Hvis der er ti jobforslag, så kan halvdelen godt være pædagogstillinger eller souschef $i$ en eller anden børnehave. Det er helt håbløst (Mikkel, ledig). 


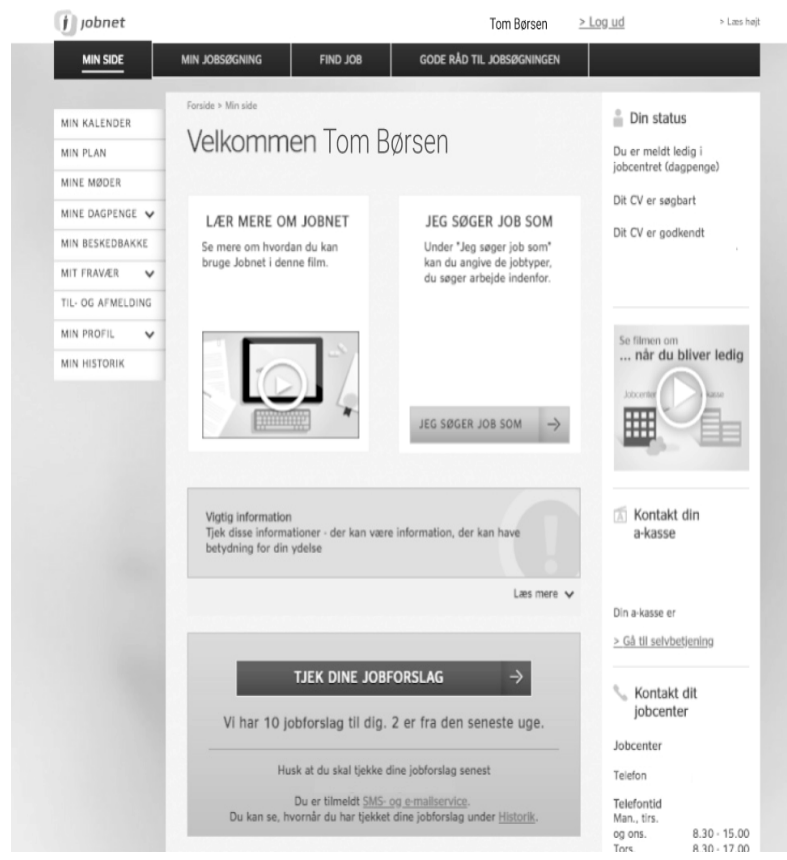

Figur 2a. Tjek dine jobforslag.

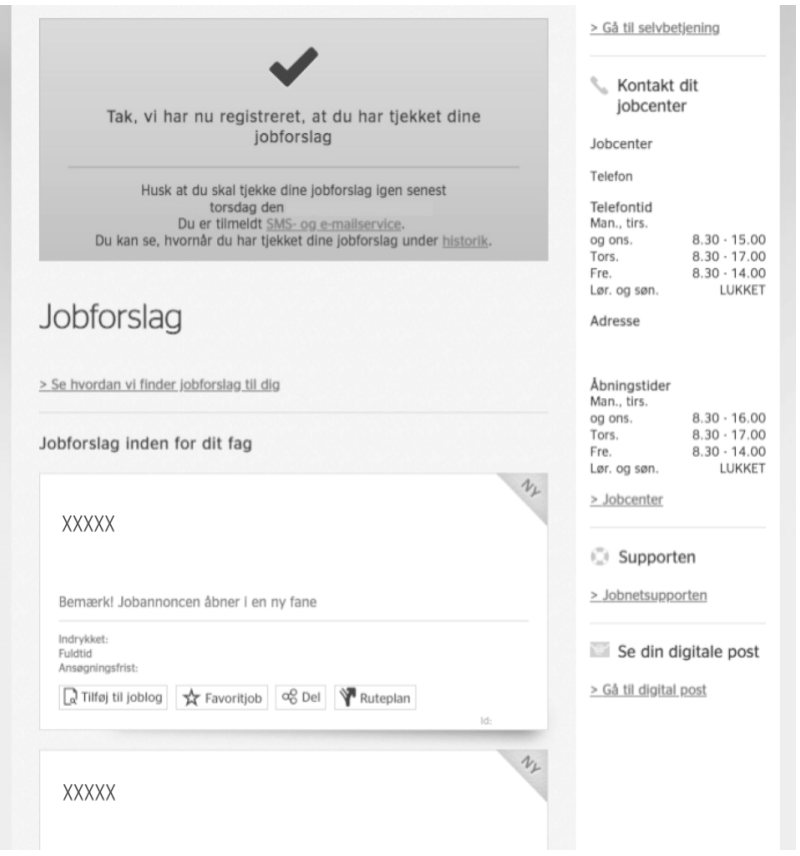

Figur 2b. Når du har trykket på „Tjek dine jobforslag“, kommer de genererede jobforslag frem. 
Når jobforslagene ikke er relevante, lader ledige være med at læse dem. „Det mest åndssvage er, at jeg jo ikke tjekker de der opslag på Jobnet, fordi jeg ikke synes, de er så gode" (Therese, ledig). De genererede jobforslag bliver beskrevet ved latter og med jokes: „Nej, der er hele to jobforslag, og det ene er i vores lokale pølsevogn. Fantastisk!“ [sagt med ironi] (Trine, ledig). Årsagerne kan være, at der ved erfaring med eksempelvis ,salg“ ikke skelnes mellem salg i en købmand eller salg inden for andre brancher. Eller at den ledige ikke har angivet, hvilke stillinger han eller hun ønsker. Mange af jobforslagene opfattes ikke som relevante eller som mismatch og medierer ikke digital individualitet. Den 1. januar 2020 er kravet om at trykke ,tjek dine jobforslag“ på Jobnet.dk minimum hver syvende dag blevet afskaffet (STAR u.d.). Systemets kunstige intelligens genererer dog fortsat jobforslag.

\section{Min plan}

„Min plan“ er en side under Jobnet.dk (Jobnet 2020). Efter samtale med en jobkonsulent indsættes „en plan for kommende aktiviteter“, som efterfølgende skal accepteres af den ledige ved at trykke, ,jeg godkender min nye plan“. Det aftalte er bindende.

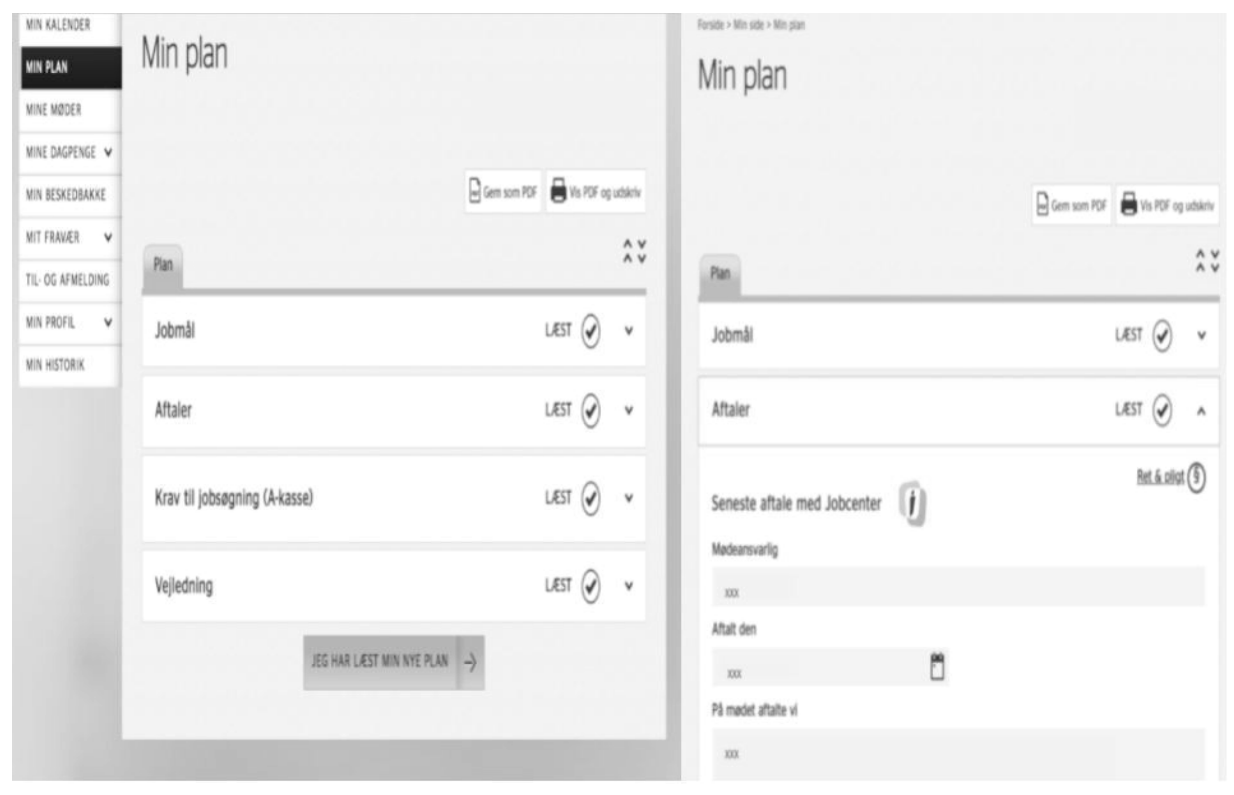

Figur 3. Min plan på Jobnet.dk. 
Ledige er bange for, at noget går galt, og for økonomisk sanktion, hvilket påvirker dem til at udvikle forskellige strategier til at sikre gyldigheden af de bindende aftaler i „Min plan“:

Blandt andet så informerede jeg om, at jeg optog samtalen, og at jeg gerne ville have et skriftligt referat sendt til min private mail, som jeg ville godkende, inden det kom op på Min plan [hvilket ledige ikke har krav på]. Min jobkonsulent, som i øvrigt gik ned med stress umiddelbart efter den samtale, begyndte simpelthen at græde, fordi hun følte, at jeg ikke havde tiltro til hendes arbejde. Hun følte, at jeg slet ikke kunne se, at hun bare gerne ville hjælpe mig med at få et arbejde. Og jeg tror endda, at jeg var relativt sød ved hende. Altså ved at sige: 'Det er ikke dig. Det er bare, fordi jeg lige vil have styr på, at ikke noget går galt, og at jeg har hørt, at det er ret vigtigt, at man har tingene på skrift, så man kan klage senere, hvis der går noget galt' (Sandra, ledig).

Ledige kan se og godkende det, som jobkonsulenter har skrevet ind i Min plan. Den ledige behøver ikke godkende Min plan, hvis vedkommende ikke er enig i det, som jobkonsulenten har skrevet. Det er både tidskrævende for jobkonsulenten og den ledige at skulle bruge tid på at sende e-mails uden om systemet. Denne mistillid til jobkonsulenterne kan dog på den anden side forklares med, at jobkonsulenterne har en høj sagsstamme af ledige. Det gør det svært at nå forberedelsen til samtalen, at informere om regler og love og samtidig skulle dokumentere det aftalte i Min plan oven i alle andre opgaver, de også varetager. Jobkonsulenterne kan derfor have svært ved at nå at skrive det hele ind i Min plan:

Vi skal kraftedeme også registrere i hoved og røv. Og nu skal du huske at lave et notat der, nu skal du huske at trykke der, nu skal du huske at afrapportere der, fordi ellers så [hun stopper op og trækker forpustet vejret ind, som om hun har talt så hurtigt, at hun har glemt at trække vejret] registreres det hele, og i morgen når du kommer ud, og du ikke har gjort det, du skulle, så bum, så står der en chef (René, a-kassejobkonsulent).

Som allerede nævnt kritiserer flere af informanterne den manglende individuelle indsats med en jobkonsulent, som kender den ledige og dennes sag. Dette afspejles i modulet Min plan, når medlemmerne beskriver, at det aftalte ikke er indskrevet, hvilket beskrives som følsomt.

Det personlige og individuelle møde er vigtigt: „Jeg kan bare bedre lide at tale med en, der kan hjælpe mig med det samme og sætte sig ind i min situation“" (Alex, ledig). Hvilket jo i sig selv er modsætningsfyldt, når mange ledige ikke har tillid til systemet og ønsker det dobbelt dokumenteret, inden de trykker ,godkend" i Min plan. Mange har selv oplevet systemfejl. Alle ledige gav udtryk for, at en jobkonsulent kan udrede en fejl med det samme, og at de digitale systemer 
ikke kan gøre det. En anden metode, som ledige bruger for at sikre sig mod fejl i Min plan, er at tage screenshots af, hvad der står på Min plan, og gemme dem.

\section{Joblog}

På Joblog dokumenterer ledige jobsøgningen. Nogle a-kasser stiller en Joblog til rådighed på deres website, der synkroniseres med Jobnet. Kravet er, at den ledige skal opdatere Joblog hver uge og have søgt minimum én officielt opslået stilling. Hvis ansøgningen ikke er dokumenteret med upload på Jobloggen, kan sanktionering forekomme. Tilgængeligheden for arbejdsmarkedet vurderes blandt andet ud fra oplysningerne om medlemmernes jobsøgningsaktivitet på Joblog. Informationen bruges også til at rådgive ledige. Jobcenter og a-kasse er forpligtede til at vejlede samt at kontrollere, om den ledige står til rådighed og overholder det aftalte på Min plan, eksempelvis om en aftalt digital jobsøgningsstrategi afspejles i Joblog.

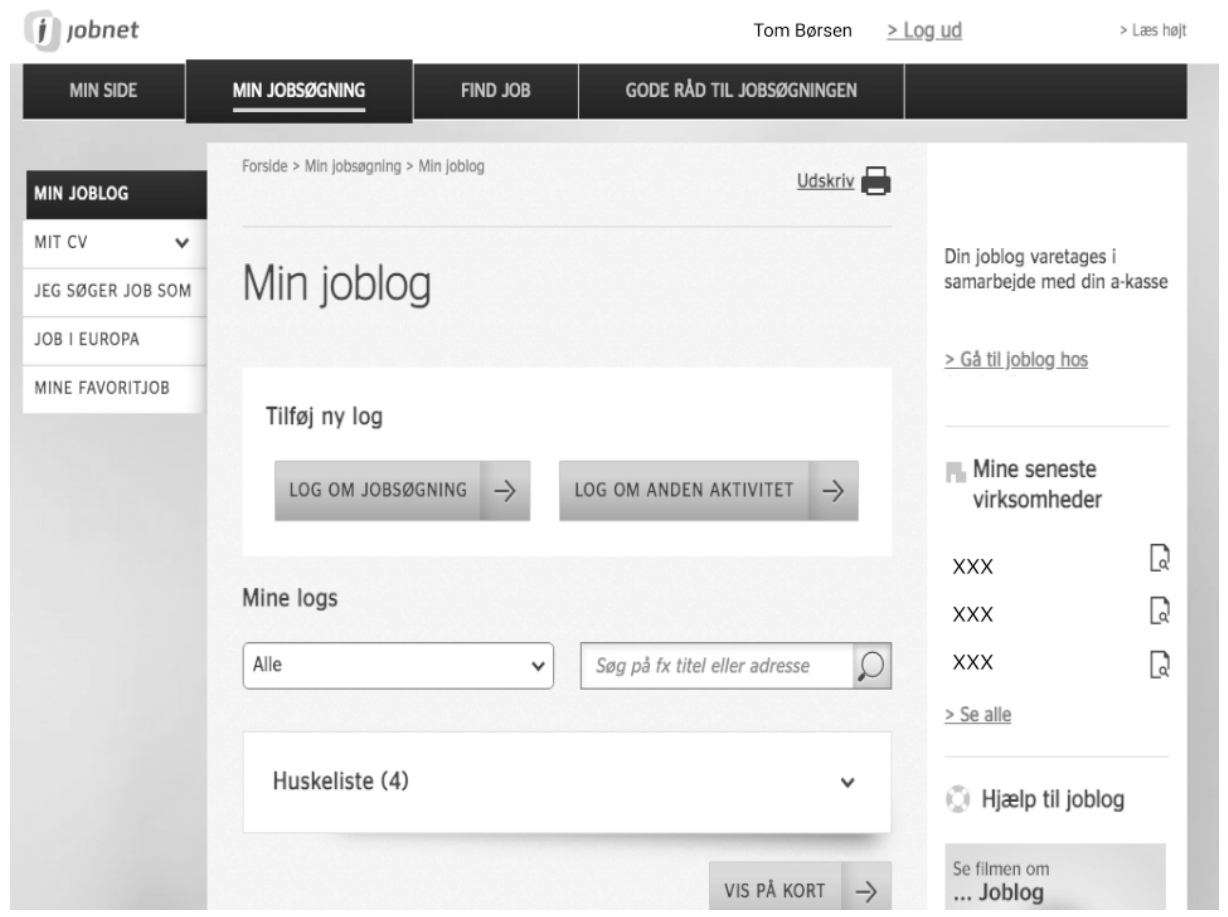

Figur 4. Joblog. Ledige skal uploade en-to ansøgninger om ugen på Min Joblog under modulet „Min Jobsøgning" eller på a-kassens website (Jobnet u.d.a). 
Størstedelen af tiden bruges på at lede efter jobs og sende ansøgninger samt på at dokumentere jobsøgningsaktiviteterne på de digitale platforme, men dokumentationen beskrives som ,spildte kræfter“. Hvis ledige ikke er aktive digitalt, går de og udtænker strategier til at håndtere Jobnets krav eller tænker på, hvad de skal gøre, nå eller mangler. Der er ikke altid nok relevante jobs at søge, og det får ledige til at lægge forskellige strategier. En måde er at søge jobs på, som de håber på ikke at få. Enten fordi de er overkvalificerede eller ikke har kompetencerne: ,Jeg har aldrig nogensinde siddet og loddet eller noget andet, vel, men det er bare for at søge arbejde. Det er ulempen, synes jeg. Man bliver nødt til at søge jobs, som man reelt set ikke ønsker“ (Rosa, ledig). Og selv om der søges jobs, som de ikke ønsker, reflekterer ledige over, at det tager tid fra dem selv og arbejdsgiverne, der skal forholde sig til disse ansøgninger. Rikke fortæller, at hun selv har været arbejdsgiver og ved, hvordan de gør, når der skal ansættes. Derfor synes hun ikke, man skal sende et fast antal ansøgninger om ugen:

Jamen, det er da spild af arbejdsgiverens tid og spild af min tid at sende en ansøgning, når jeg ikke har lyst til at få jobbet. Jeg har også selv prøvet at få jobansøgninger. I den første sortering tager man dem fra, der skal søge, og så lægger man 50 procent væk. Man spilder jo folks tid med sådan noget. Det er en af de ting, man burde lave om. Man skal ikke sende fast. Det er ligesom at sige, at du skal gå ud og skide klokken ni om morgenen, det kan man da ikke (Rikke, ledig).

En anden måde, som medlemmerne vælger at indrette sig på, hvis der ikke nu skulle være jobs at søge, er ved at gemme allerede sendte ansøgninger og fordele dem på de følgende uger:

Der kan godt være en uge, hvor der har være en fire-fem stykker. Så har jeg også søgt dem. Men ellers har jeg gjort det sådan, at jeg har gemt en eller to jobansøgninger, som jeg ikke har dokumenteret, fordi hvis der nu kun er en i næste uge ... Og de ser jo meget på, at der absolut skal ligge to om ugen. Man kan ikke lægge fem i en uge og ingen i de følgende uger. Man gør jo, som man skal. 200 ansøgninger har jeg da i hvert fald sendt (Signe, ledig).

En tredje måde er at dokumentere med falske ansøgninger i Joblog, hvis der ikke er jobs at søge, eller hvis det digitale format ikke passer: eksempelvis videoansøgninger, der ikke kan uploades på Joblog som primær ansøgning: „Så uploader jeg sådan to phoney ansøgninger" (Sandra, ledig). Da Sandra ikke kan dokumentere sine ansøgninger i videoformat, er hun bange for at blive afsløret $i$ at uploade falske ansøgninger, selv om hun søger det tredobbelte af, hvad hun skal på en uge. Informanterne beskriver dokumentationskravet med ord som „,kontrol“ og „overvågning“. Når rationalet er, at medlemmerne skal dokumentere det ansøgte, for at de også kan få bedre råd og vejledning samt effektivisere 
jobprocessen, er der risiko for, at tilbuddet om hjælp drukner i kravet om kontrol. „Altså, der er flere gange, hvor jeg har tænkt, at det sgu da ikke er brugerne, der bliver hjulpet" (Agnes, ledig). Jobloggen tjener med andre ord ikke lediges interesser, da funktionen opfattes som et adfærdsstyrende kontrolorgan. Lediges utilfredshed med kontrollen viser sig som mistillid til systemet, som gør, at de får mindre søgemod: ,Jeg har overhovedet heller ikke brug for at blive kontrolleret, det gør bare, at jeg har mindre mod på at søge" (Sofia, ledig). Ledige finder ikke, at Joblog støtter dem på vej i job, og udtænker strategier, som tager tid fra dem selv og jobkonsulenterne.

\section{Digitale værktøjer medierer ikke individuel jobsøgning}

Ovenfor er gennemgået nogle af dagpengesystemets digitale elementer, og det er beskrevet, hvordan de opleves af ledige brugere. De ledige synes ikke, at de digitale værktøjer støtter dem i deres jobsøgning. Deres erfaringer forgrener sig som mistillid til jobkonsulenter og systemet, hvilket făr dem til at sende falske ansøgninger eller optage samtaler med jobkonsulenter. Det er vanskeligt at udføre digitale pligter, da det er svært at orientere sig i dagpengesystemets digitale platforme. Bare det at melde sig ledig er en udfordring for mange. Sproget er svært, kompliceret og vanskeligt tilgængeligt. Der kommer nogle gange forskellige udmeldinger fra systemets forskellige aktører. Det er svært at få svar på tvivlsspørgsmål. Alt dette genererer en følelse af usikkerhed hos ledige, der frygter for deres dagpenge, som er deres eksistensgrundlag.

De digitale styringsværktøjer bliver ikke alle opfattet som relevante, da de vanskeliggør individuel betjening. Hvilken jobkonsulent man har booket et møde med, betyder ikke noget, da møder ofte aflyses, eller der dukker en anden jobkonsulent op end hende, som er booket til møde. De jobforslag, som systemet finder frem i Jobforslag, opleves som generiske og sjældent relevante.

Nogle ledige oplever, at jobkonsulenter manipulerer med beskrivelserne af indgåede aftaler i Min plan. Samtidig manipulerer ledige med jobansøgninger: Gamle og falske ansøgninger uploades på Joblog. De ledige søger jobs, de ikke ønsker eller er kvalificerede til. Samlet set både peger det på og bidrager til mistillid til systemet.

Ledige giver udtryk for, at de frygter at blive økonomisk sanktioneret, hvis det „bliver opdaget“, at de har udtalt sig og kritiseret dagpengesystemet. Dette vidner om manglende tro på systemet $\mathrm{og}$ lediges demokratiske rettigheder. Frygten for sanktioner forstærkes af sprogbrugen i mails og beskeder, som modtages på de to platforme: 
Der er altid en trussel med. Altså, det er ligesom om, at de lige skal have den der med om, at der er nogen, der ikke kan finde ud af det. Det kan da godt være, men vi er nok mange, der godt kan. Vi behøves ikke lige at skulle trues med, at vi mister vores dagpenge, når vi føler, at vi gør det, vi skal (Agnes, ledig).

William beskriver det som, ,[...] at der næsten står 'fuck dig til sidst'. Det er de her ting, du skal gøre. Hvis du ikke gør det, så skal du være opmærksom på, ikke at du bliver straffet, men at det kan have konsekvenser for dine dagpenge. Jeg hader de der pegefingre!“(William, ledig). Sprogbrugen i teksterne opfattes af nogle som en løftet pegefinger, som styrker modviljen mod de digitale pligter. Årsagen til denne opfattelse kan både findes i de tekster, der afsendes fra dagpengesystemet, og i, at ledige retter deres frustration over ikke at komme i beskæftigelse mod systemet. Et muligt eksempel på det, Agnes, William og andre ledige reagerer på, er følgende vending: „Får du ikke booket rettidigt ... har det konsekvenser for din dagpengeret. Du bliver nemlig automatisk afmeldt jobcentret, hvis du ikke har booket en samtale inden for fristen" (udsnit af mødebrev fra Akademikernes A-kasse).

Tanken om at få frataget dagpengeretten påvirker ledige, som bruger en stor del af tiden på at tænke over de digitale pligter: Overses information, fejler systemet, burde man have taget et screenshot? „I starten var jeg usikker på, om jeg ville misse vigtig information, $o g$ at det ville skade min status og mulighed for at modtage dagpenge“ (Helle, ledig). Medlemmerne føler, at der er mange digitale pligter, der skal huskes, hvilket medfører en følelse af stress.

[D]et kan stresse en lidt, synes jeg. Det der med, om du nu har husket at tjekke det hele. Om du nu har husket at sige dut der, sat hak der og alt det der. Jamen, det er jo, fordi man hele tiden tænker, at man bliver ramt, hvis man ikke har gjort det (Rosa, ledig).

Endvidere udtaler en, som har været ledig før, at kontrol i ledighedssystemet engang var baseret på lediges psykiske velbefindende, men at det i dag er baseret på kontrol: „Dengang følte jeg egentlig mere, at det var en kontrol af, om folk havde det godt, og at de ikke gik psykisk ned på det. I dag der føler jeg måske mere, at det bare er kontrol" (Sanne, ledig).

Alle de interviewede a-kassemedlemmer fortæller, at de ikke ønsker økonomisk sanktionering. En sanktionering beskrives som: „meget traumatisk. Jeg havde ingen dagpenge. Det er hele ens eksistensgrundlag, der forsvinder" (Morten, ledig). Andre informanter benytter ord som „bange“ eller „umyndiggjort“. De digitale styringsværktøjer repræsenterer på den måde en frygt, som gør, at flertallet af ledige arrangerer sig helt anderledes end tiltænkt på måder, som besværliggør det for dem selv eller for jobkonsulenterne. Dagpengesystemets digitale værktøjer reflekterer ikke det dobbelte formål - både at kontrollere og støtte de 
ledige i deres jobsøgning - som lovgivningen foreskriver. For at forklare dette kan vi gå tilbage til en af KTT's og Andrew Feenbergs inspirationskilder, til den første generation af Frankfurterskolen (Jay 1996). De undersøgte det moderne samfund, som de påviste i høj er grad styret af instrumentel fornuft. Historisk set har det været en dialektisk proces, hvor den instrumentelle fornuft bliver til sin egen antitese: en ny form for tvang (Horkheimer \& Adorno 1997). Et samfund, som primært styres af instrumentel fornuft, er ,endimensionelt“" (Marcuse 2013). I dette studie viser den instrumentelle fornuft sig i dagpengesystemets digitale platforme gennem et endimensionalt fokus på kontrol af lediges handlinger. Men den instrumentelle fornuft hviler her på en forestilling om, at ledige dagpengemodtagere ikke vil gøre en tilstrækkelig indsats for at komme i beskæftigelse, hvis de ikke bliver kontrolleret.

\section{Rekontektualisering gennem demokratisk deltagelse}

Der findes imidlertid alternativer til den instrumentelle fornuft, og det er muligt at gå videre end blot at dekontekstualisere en teknologi. Efter at vi har dekontekstualiseret dagpengesystemets digitale platforme, vil vi derfor ved hjælp af lediges input rekontekstualisere de digitale platforme ved at foreslå en ny balance mellem den instrumentelle fornuft og en brugerinvolverende rationalitet.

Teknologier er multistabile. De kan eksistere i flere konfigurationer. Dagpengesystemet og de digitale styringsværktøjer er i dag effektive til at få ledige akassemedlemmer til at udføre bestemte handlinger på nettet. De opfattes slet ikke altid som effektive til at understøtte ledige i deres bestræbelser på at komme i beskæftigelse. De ender med at udvikle strategier, der ikke er fokuseret på jobsøgning, men på at opfylde systemets krav. Der skal en rekontekstualisering af de digitale ressourcer til. Teknologier er multistabile i den forstand, at de kan konfigureres forskelligt. Forskellige teknologiske konfigurationer er mulige, og deres stabilitet afhænger af omgivelserne. Teknologi kan både designes til at intensivere kontrol og til at understøtte kommunikation og medindflydelse. Derfor kan teknologier redesignes gennem demokratisk medinddragelse. Om de så er stabile, afhænger af konteksten. Startpunktet for rekontekstualiseringen er inddragelse af sårbare grupper:

Kritisk teori fastholder, at der kan være mindst to forskellige kulturelle arrangementer, der udvikler sig i samspil med forskellige teknologier. Udgangspunktet for en ny vej må ikke søges i spekulative teknologiske fantasier, men blandt marginaliserede teknologibrugere i det eksisterende system. Teknologier, der svarer til forskellige kulturelle arrangementer, sameksisterer således allerede i vores eksisterende samfund (Feenberg 2002:15; vores oversættelse). 
Ifølge Feenberg er rekontekstualiseringen af en ekskluderende teknologi baseret på empati og demokratisk samtale og ikke på overvejelser om effektivitet og hierarki. Ofte henvises der til Habermas' (2015) filosofiske tekster om kommunikativ handling, men i teknoantropologien er KTT snarere knyttet til aktionsforskning, som:

... er en deltagende proces, der ... søger at samle aktion og refleksion, teori og praksis, i samspil med andre i jagten efter praktiske løsninger på spørgsmål, som er af presserende betydning for mennesker (Bradbury 2015:4; vores oversættelse).

Vi har identificeret følgende input til rekontekstualisering af dagpengesystemets digitale styringsværktøjer: Mette (a-kasse, lederniveau) ønsker, at de digitale platforme sammenlægges til én samlet platform, der skal understøttes med grundlæggende vejledningsmateriale. Det vil afskaffe den ukoordinerede information og lette den svære opstart. En ledig foreslår trinvis information: „Og den der information: Det ville være helt vildt fedt, hvis der var sådan et trinsystem, der fortæller præcis, hvad skal jeg gøre, efter jeg har gjort det her. Det ville gøre alt" (Mille, ledig). Ovenstående flugter med at samle beskæftigelsesindsatsen ét sted, som også administrerende direktør i a-kassen ASE Karsten Mølgaard Jensen og Radikale Venstres tidligere beskæftigelsesordfører Sofie Carsten Nielsen har foreslået.

Der bliver også ønsket en tjekliste, så man ved, hvad man skal gøre, når man bliver ledig. Det kunne være med til at afhjælpe usikkerheden om, hvorvidt man gør det rigtigt:

Så der følte jeg måske nok lige lidt, at, puha, at det var lang tid, inden at man begynder at få lidt at vide, om man har gjort det rigtigt med at melde sig ledig, og om det hele det fungerede, som det skal. Efterfølgende kom der en tjekliste fra a-kassen med, hvad man skal gøre. Så jo, i mit tilfælde kunne jeg se, at jeg havde gjort det rigtigt nok. Men det havde været rart, hvis man fik tjeklisten på forhånd eller den første dag, at man melder sig ledig. Så får man en fornemmelse af, at du har fået det hele med (Alma, ledig).

Præsentations-CV'et under modulet „Min jobsøgning“ på Jobnet.dk er en digital CV-skabelon, som ledige omtaler positivt. Her fremhæves det af ledige, der ikke har skrevet CV før, eller som ikke er digitalt stærke, at CV-skabelonen er let at bruge:

Jeg kan ikke skrive CV uden en skabelon. Det skal deles i en, to, tre dele. Først så skriver man dato, så skriver man, hvad det er, man har lavet, og så skriver man et eller andet, jeg kan ikke lige huske det. Det der er på Jobnet, det er meget nemmere. Det kan jeg finde ud af, og det kan jeg håndtere. Det bliver, hvor det 
bliver. Jeg har sendt en ansøgning, hvor jeg fandt ud af, de ikke havde fået hele mit CV, fordi der stod, at man skulle PDF'e det [gemme det i PDF-format]. Ja, det er jo også noget nyt for mig at lave det om, man har skrevet, til en PDF-fil. Jeg havde åbenbart fået sendt en word-fil uden at have fået lavet en PDF-fil, og så er der nogle ting, der forsvinder. Sådan noget, det tør jeg ikke sende af sted, eller det gider jeg ikke. Så kan det være det samme (Lene, ledig).

Det understøttende modul ,præsentations-CV“ (Jobnet u.d.d) kan være med til at understøtte jobsøgendes digitale identitet, hvis de ikke har skrevet et CV før. Det kan let printes eller gemmes som PDF efterfølgende. CV-modulet er altså et af de eksisterende elementer i dagpengesystemets digitale værktøjskasse, der faktisk fungerer og støtter de ledige.

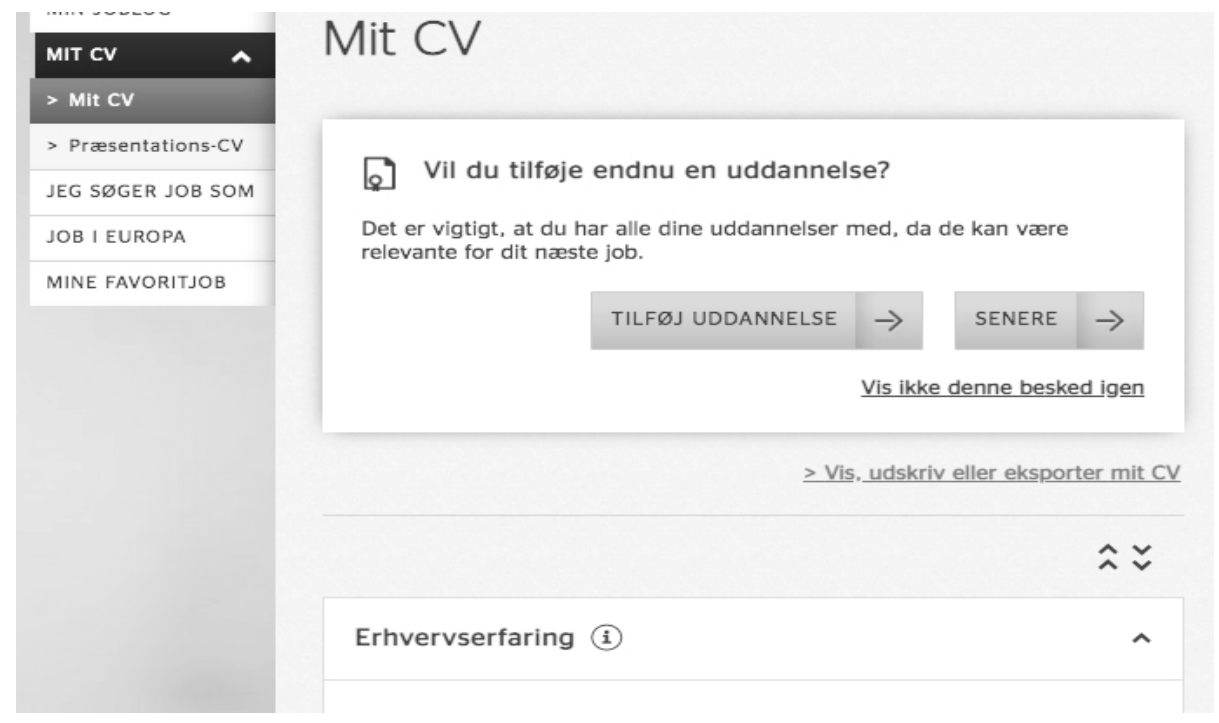

Figur 5. „Mit CV“ på Jobnet.dk.

Andre enkelte forslag er en algoritme, som genererer en kalenderoversigt med de pligter, der skal udføres, så man ved, hvornår man skal hvad. Endvidere foreslås en forenkling af blanketterne, at skære ned på de lange sætninger og indsætte en hjælpefunktion, så man kan finde den hjælp, man skal bruge, at etablere en chatfunktion, så man hurtigt kan få svar på spørgsmål, samt at benytte Skype til møder, hvis man har langt til mødelokationen. Flertallet af ledige er enige i, at kravet om den ugentlige dokumentation af jobansøgninger bør fjernes: „Søg de jobs, du har lyst til, og som er relevante. Og ikke så meget dokumentation på det ene og det andet, hvor du skal ind og udfylde på nettet" (Jesper, ledig). Ifølge Mette (Mette, a-kasse, lederniveau) bør Joblog følge digitalt med, så den muliggør dokumentation, der har andre formater end den traditionelle jobansøgning: 
[D]igitalt skulle man understøtte, at man i dag rekrutterer på alle mulige forskellige måder ved hjælp af særligt LinkedIn og Facebook. Altså, hvis du primært søger via netværk, LinkedIn og sådan nogle ting, så står du ikke til rådighed, fordi du skal lave en skriftlig ansøgning som et svar på en stillingsannonce. Vi bevæger os over i et helt andet jobmarked, hvor tingene skal gå meget hurtigere end det med at opslå en stillingsannonce, hvor man har tre ugers frist til at ansøge og efterfølgende en periode, hvor man skal til samtale og måske også en 2. samtale. I nogle virksomheder går det bare meget hurtigere, og det foregår på en helt anden måde.

En forenkling af hele systemet vil „,simpelthen gøre det enklere og fjerne alle de små krøller, der er i systemet. Få dem væk, og lav et helt enkelt system“ (Barbara, ledig). Og medarbejdere i a-kasser og jobcentre ønsker også at tilpasse indsatsen til hvert enkelt medlem, hvilket vil sige ,mindre kontrol, mere tillid, mere fokus på hjælp, væk fra alt bureaukratiet" (Kåre, a-kasse, lederniveau). Det ville samtidig understøtte alle informanternes største udtrykte ønske: „Det ville være, hvor de gik ind og tog mig som individ“ (Jytte, ledig). Midlet kunne være et digitalt system, som er ,præcist, specifikt skræddersyet til mig“ (Elias, ledig), og med dagpengeregler, som er tilpasset samtiden: ,[Politikerne skal] prøve at få tilpasset reglerne efter den virkelighed, der nu er kommet de sidste ti år. Jeg har bare følt, at det var en form for en proces, hvor jeg bare var et tandhjul. Men jeg vil da hellere have, at det var mere Oscar-rettet, end det var sådan arbejdsløshedsrettet" (Oscar, ledig).

Denne digitalt medierede individualitet implicerer fx relevante jobforslag og en håndholdt indsats med den samme jobkonsulent, man eventuelt kan møde online. Det vil virke tillidsskabende og modvirke den mistillid, ledige har til systemet, „ved at vende tilbage til én kontaktperson, hvor der er en mailadresse og et telefonnummer til en, som kender ens sag“ (Morten, ledig). Der er ønsker om coaching eller hjælp til at strukturere sig selv og psyken, enten ved tilbud om træningsforløb eller - som Lene udtrykker det - „en „stopknap“ eller en „nødknap“, man kan trykke på, der siger, „nu skal jeg have hjælp!“(Lene, ledig). Endvidere foreslås en bostøtte- eller mentorordning i stedet for økonomiske sanktioner.

Der er generelt et ønske om mere direkte kontakt med jobkonsulenterne, da ledige ofte oplever, at jobkonsulenterne kan løse et problem med det samme, enten pr. telefon, via et fysisk møde eller online. Der er endvidere et ønske om at blive anset som et individ med unikke behov og ikke bare en sag i bunken; at interaktionen tager udgangspunkt i den enkelte. Der ønskes mere digital individualitet og mere individualitet i møderne. Det betyder længere møder, og at jobkonsulenterne skal have ordentlig forberedelsestid. Andre foreslår flere uddannelsesmuligheder for at få kompetencer, der er efterspørgsel på. Det er for eksempel ældre ledige med en uddannelse, som ikke længere eksisterer, eller ny- 
uddannede, som ikke er kommet i job inden for et år. En forlænget dagpengeperiode og forlænget mulighed for supplerende dagpenge ønskes også. Dette har dog ikke direkte noget med de digitale værktøjer at gøre, omend det kulturelle og tekniske hænger sammen.

\section{Konklusion}

Der er ingen tvivl om, at det at være ledig er forbundet med stor usikkerhed, og at ledigheden påvirker ledige a-kassemedlemmer og deres netværk. Alle ønsker brændende et job og yder deres bedste for at navigere i dagpengesystemet. Lediges oplevelser med dagpengesystemets digitale styringsværktøjer er præget af adfærdsregulerende kontroltænkning samt overvågning. I denne artikel vises, at ledige mener, at dagpengesystemets digitale ressourcer hverken effektiviserer jobsøgningen eller ser dem som individer. De lediges erfaringer ansporer til ,ulydige handlinger". Et flertal har prøvet at skrive eller skriver falske ansøgninger. Frygten for at blive økonomisk sanktioneret påvirker altså adfærden og trækker opmærksomheden væk fra meningsfulde jobsøgningsaktiviteter. Kontrollen er blevet en uafbrudt advarsel om økonomisk sanktion, hvis ledige ikke lever op til rådigheds- og aktivitetskravet. De detaljerede krav til dokumentation af lediges jobsøgning er således med til at opretholde en myte om, at kontrol af ledige støtter dem $i$ at komme i beskæftigelse. Denne myte er indlejret i dagpengesystemets digitale ressourcer, som altså ikke støtter de ledige. De digitale værktøjer opfattes derfor som irriterende, tåbelige og unyttige, fordi de ikke understøtter jobsøgningen.

Inspireret af KTT anbefales det, at de digitale ressourcer dekontekstualiseres fra den kontrolorienterede tilgang, som i dag dikterer det tekniske design af dagpengesystemets digitale værktøjer, til digitalt medieret individuel jobsøgning. Dagpengesystemets digitale ressourcer bør med andre ord rekontekstualiseres, så de bliver mere effektive i forhold til at understøtte den enkelte ledige $\mathrm{i}$ at komme i relevant beskæftigelse. Det betyder ikke, at digitalt medieret individuel jobsøgning får alle ledige i relevant beskæftigelse, men en rekontekstualisering vil betyde noget for de lediges oplevelse af dagpengesystemets digitale ressourcer. Fra at være noget, der modarbejder dem, vil det være noget, de synes er nyttigt, og som forhåbentlig også mere effektivt vil bidrage til at få dem i beskæftigelse. Et forslag til en sådan rekontekstualisering kunne være, at kravene om dokumentation af jobsøgningsaktiviteter lempes. Det vil både frigøre ressourcer til egentlig jobsøgning og afhjælpe følelsen af stress og angst. Hermed ikke sagt, at en rekonstruktion vil være let. Det er aldrig let at inkludere marginaliserede brugergruppers interesser. Det kræver den rette kontekst, politisk vilje 
og viden om, hvad de ledige ser muligheder i. Det er sidstnævnte bidrag, denne artikel kommer med input til.

Både ledige og jobkonsulenter ønsker et mere tillidsbaseret system, som ikke blot understøtter jobsøgning, men „stilladserer“ ledige som hele mennesker. Frem for blot helt at fjerne digitale styringsværktøjer er løsningen at rekontekstualisere og redesigne dem, så de understøtter den enkeltes jobsøgning i et samlet digitalt koordineret system. Opbygningen af de digitale websites skal således guides af funktioner, der understøtter opbygning og præsentation af den lediges individuelle digitale identitet. Det anbefales videre, at systemet opsættes sådan, at enhver ledig oplever en digitalt medieret individuel indsats, der kan erstatte den tidligere faste, tilknyttede jobkonsulent, som flere ledige forestiller sig skaber kontinuitet, individualitet, tryghed og tillid i sagsbehandlingen. Vi foreslår således ikke at vende tilbage til „de gode gamle dage" med personlige møder, men vi forestiller os, at teknologien medierer personlige relationer mellem fast konsulent og ledig. Udfordringen er at individualisere dagpengesystemets ressourcer, så de flugter med intentionen om at understøtte ledige i jobsøgningen, effektivisere administrative processer og gøre styring af brugeres adfærd transparent.

\section{Note}

1. Vi introducerede os selv og undersøgelsen til intromøderne. Vi bad dem, der ønskede at deltage $i$ et interview, om at rette henvendelse til os. Informanterne skulle nemlig ikke føle sig pressede til at deltage, og samtidig måtte de gerne have forholdt sig til undersøgelsens problematik. Verbalt aggressive personer blev frasorteret, da det tog fokus væk fra undersøgelsens tema. Udvælgelseskriterierne kan have haft effekt på vores fund, idet vi både har fravalgt ledige, som var direkte aggressive mod os eller systemet, og ledige, der ikke selv meldte sig som interviewpersoner. Vi mangler derfor de fravalgte lediges synspunkter. Endvidere vil nogle informanters svar afspejle, at de er nyledige, der har begyndervanskeligheder med systemets digitale ressourcer. De interviewede ledige er medlem af 10 forskellige a-kasser. De fleste havde, da de blev interviewet, meldt sig ledige inden for de seneste 6 måneder, to var overgået fra sygedagpenge, og ti havde været ledige i op til et år. De interviewede tæller både personer, der er blevet ledige for første gang, og personer, der tidligere har været ledige, er kommet $\mathrm{i}$ beskæftigelse og igen er blevet ledige. Blandt de interviewede var der 16 kvinder og 14 mænd, hvis uddannelsesniveau varierer fra kort (11), mellemlang (8) til lang videregående (11). 17 informanter boede øst og 13 vest for Storebælt. Deres aldersfordeling var følgende 18-29: 9, 30-49: 11, 50: 10. Det samlede indtryk af interviewene var overraskende ensartet. På trods af at hver interviewet person har sin egen historie, er opfattelserne af de digitale systemer ikke meget forskellige. Vi kan ikke lokalisere kritikken af de digitale systemer, hvilke muligheder de giver, og forslagene til, hvordan de kan forbedres, til et enkelt segment af ledige.

\section{Litteratur}

Beskæftigelsesministeriet

Uden dato Den danske model. https://bm.dk/arbejdsomraader/arbejdsvilkaar/den-danskemodel/. Læst 5.11.2019. 
Bradbury, Hilary (ed.)

2015 The Sage Handbook of Action Research. $3^{\text {rd }}$ edition. London, Thousand Oaks, New Delhi \& Singapore: Sage.

Brinkmann, Svend \& Lene Tanggaard

2015 Kvalitative metoder. En grundbog. København: Hans Reitzels Forlag.

Børsen, Tom

2020 Bridging Critical Constructivism and Postphenomenology at Techno-

Anthropology. Technei. Research in Philosophy and Technology 24(1):218-46.

DOI: https://doi.org/10.5840/techne2020320122.

Callon, Michel

1984 Some Elements of a Sociology of Translation. Domestication of the Scallops and the Fishermen of St Brieuc Bay. The Sociological Review 32(1 suppl):196-233. DOI: https://doi.org/10.1111/j.1467-954X.1984.tb00113.x.

Dagpengekommissionen

2015 Dagpengekommissionens samlede anbefalinger. https://bm.dk/media/6477/ hovedrapport-pdf-pdf.pdf. Læst 27.06.2019.

Ekspertgruppen

2014 Ekspertgruppen om udredning af den aktive beskæftigelsesindsats veje til job. En arbejdsmarkedsindsats med mening. https://bm.dk/media/6779/carsten-kochudvalget-web-pdf.pdf. Læst 13.5.2019.

Feenberg, Andrew

2017 Technosystem. The Social Life of Reason. Cambridge, MA: Harvard University Press.

Feenberg, Andrew

2002 Transforming Technology. A Critical Theory Revisited. New York: Oxford University Press.

Geertz, Clifford

1973 Thick Description. Toward an Interpretive Theory of Culture. In: C. Geertz:

The Interpretation of Cultures. Pp. 3-30. New York: Basic Books.

Habermas, Jürgen

2015 [1981] The Theory of Communicative Action. Volume 2. Lifeworld and Systems.

A Critique of Functionalist Reason. Hoboken, NJ: John Wiley \& Sons. http://nbnresolving.de /urn:nbn:de:101:1-201511114002.

Hansen, Hans-Tore, Kjetil Lundberg \& Liv Johanne Syltevik

2018 Digitalization, Street-Level Bureaucracy and Welfare Users' Experiences. Social Policy \& Administration 52(1):67-90. DOI: 10.1111/spol.12283.

Horkheimer, Max \& Theodor W. Adorno

1997 [1947] Dialectic of Enlightenment. London: Blackwell Verso.

Immervol, Herwig et al.

2020 Social Protection in the Face of Digitalisation and Labour Market

Transformations. In: W. Hynes, M. Lees \& J. M. Müller (eds): Systemic Thinking for Policy Making. The Potential of Systems Analysis for Addressing Global Policy Challenges in the 21st Century. Pp. 99-111. Paris: OECD Publishing. DOI: https://doi.org/10.1787/3f4ef6f1-en. 
Ishøy, Søren Kjellberg

2019a Jobcentercirkus for milliarder. Kun én ud af ti kommer i job. B.T. 3.6. https:// www.bt.dk/samfund/jobcentercirkus-for-milliarder-kun-en-ud-af-ti-kommer-i-job. Læst 18.7.2019.

2019b Jobcentercirkus. Elektriker-Michael maitte søge job som lægesekretær. B.T. 2.6. https://www.bt.dk/samfund/jobcentercirkus-elektriker-michael-maatte-soege-jobsom-laegesekretaer. Læst 20.7.2019.

Jay, Martin

1996 [1973] The Dialectical Imagination. A History of the Frankfurt School and the Institute of Social Research, 1923-1950. Berkeley: University of California Press.

Jensen, Karsten Mølgaard

$2018 \quad$ Lyt til de ledige, og giv dem en chance. Kronik, Politiken 22.8. https://

politiken.dk/debat/kroniken/art6670052/Vi-bruger-milliarder-af-skattekronerp\%C3\%A5-et-bureaukratisk-system-baseret-p\%C3\%A5-mistillid-og-myten-omden-dovne-ledige. Læst 15.8.2019.

Jobnet

Uden dato a Min Joblog. https://job.jobnet.dk/CV/Jobseeking/Joblog/Overview. Læst 10.9.2019.

Uden dato b Møder. https://job.jobnet.dk/CV/Citizen/Interview/InterviewOverview. Læst 23.9.2019.

Uden dato c Rekruttering ved annoncering. https://info.jobnet.dk/da/arbejdsgiver/fakta-omjobcentrenes-tilbud/rekruttering-ved- annoncering. Læst 19.9.2019.

Uden dato d Mit CV. https://job.jobnet.dk/CV/Jobseeking/CV. Læst 13.9.2019.

2015 Om Jobnet. https://info.jobnet.dk/om-jobnet. Læst 10.9.2019.

2020 Min plan. https://job.jobnet.dk/cv/citizen/myplan. Læst 21.1.2020.

Krogstrup, Hanne Kathrine \& Søren Kristiansen

1999 Deltagende observation. Introduktion til en samfundsvidenskabelig metode.

København: Hans Reitzels Forlag.

Larsen, Rune Engelbreth

2013 Ledighed og ledighad. Kritisk analyse af et politisk normskred. Aarhus: Dana.

Marcuse, Herbert

2013 [1964] One-Dimensional Man. Studies in the Ideology of Advanced Industrial Society. London: Routledge Classics.

Masemann, Vandra Lea

1982 Critical Ethnography in the Study of Comparative Education. Comparative Education Review 26(1):1-15. DOI: https://doi.org/10.1086/446259.

Mokyr, Joel, Chris Vickers \& Nicolas L. Ziebarth

2015 The History of Technological Anxiety and the Future of Economic Growth. Is This Time Different? Journal of Economic Perspectives 29(3):31-50. DOI: 10.1257/jep.29.3.31.

Nordt, Carlos, Ingeborg Warnke, Erich Seifritz \& Wolfram Kawohl

2015 Modelling Suicide and Unemployment. A Longitudinal Analysis Covering 63 Countries, 2000-11. The Lancet Psychiatry 2(3):239-45. DOI: https://doi.org/ 10.1016/S2215-0366(14)00118-7. 
Pultz, Sabina

2018a Jeg vil ikke i fængsel. Om den affektive ledelse af de arbejdsløses selvledelse. Tidsskrift for professionsstudier 14(27):78-90. DOI: https://tidsskrift.dk/tipro/ article/view/110406/159687.

2018b Flexibility in Research Design. How Unexpected Events Can Improve Learning and Research. London: Sage. DOI: https://dx.doi.org/10.4135/9781526435217.

Ritzau

2016 A-kasser. Nye dagpengeregler er endnu mere indviklede. Information 10.3. https: //www.information.dk/telegram/2016/03/a-kasser-nye-dagpengeregler-endnumere-indviklede. Læst 12.8.2019.

STAR Styrelsen for Arbejdsmarked og Rekruttering

Uden dato a Vejledning om lov om en aktiv beskæftigelsesindsats. Styrelsen for Arbejdsmarked og Rekruttering. https://star.dk/media/11676/startvejledning.pdf. Læst 21.12.2019.

2020 A-kasser og A-kassernes brancheorganisation. Styrelsen for Arbejdsmarked og Rekruttering. https://star.dk/tilsyn-kontrol-og- klager-over-a-kassernes-afgoerelser/ tilsyn-og-kontrol-med-a-kasser/oversigt-over-a-kasserne/. Læst 1.2.2020. 